\title{
Natural Diet of Neohelice granulata (Dana, 1851) (Crustacea, Varunidae) in Two Salt Marshes of the Estuarine Region of the Lagoa dos Patos Lagoon
}

\author{
Roberta Araujo Barutot ${ }^{1 *}$, Fernando D'Incao ${ }^{1}$ and Duane Barros Fonseca ${ }^{2}$ \\ ${ }^{1}$ Instituto de Oceanografia; Universidade Federal do Rio Grande; 96201-900; Rio Grande - RS - Brasil. ${ }^{2}$ Instituto \\ de Ciências Biológicas; Universidade Federal do Rio Grande; 96201-900; Rio Grande - RS - Brasil
}

\begin{abstract}
Natural diet of Neohelice granulata in two salt marshes of Lagoa dos Patos, RS were studied. Sampling was performed seasonally and crabs were captured by hand by three persons during one hour, fixed in formaldehyde (4\%) during $24 \mathrm{~h}$, transferred to alcohol (70\%). Each foregut was weighed and repletion level was determined. Differences between sexes in the frequencies of occurrence of items were tested by $\chi^{2}$ test. A total of 452 guts were analyzed. Quali-quantitative analyses were calculated following the method of relative frequency occurrence and relative frequency of the points. At both sites, for both sexes and in all seasons, the main food items were sediment, Spartina sp. and plant detritus. The highest values of mean repletion index were estimated for the spring and summer. Analysing both salt marshes, in different seasons significant shifts in the natural diet of Neohelice granulata was not observed throughout the period of study.
\end{abstract}

Key words: Crustacea, Brachyura, diet, salt marsh

\section{INTRODUCTION}

Clarification of trophic relationships is one important approach for understanding the organization of communities. Salt marshes are very important environments as they are important sites for feeding and reproduction of invertebrates and vertebrates (Lana and Guiss, 1992). Inhabiting this environment, $N$. granulata plays important ecological roles in structuring plant communities (Costa et al., 2003), in nutrients recycling (Gutiérrez et al., 2006), and by decreasing the amount of organic matter exported from salt marshes (Botto and Iribarne, 2000).
Neohelice granulata (Dana, 1851) is a crab found in salt marshes and mangroves of the Southern Atlantic Coast, from Rio de Janeiro (Brazil) to Patagonia (Argentina) (Melo, 1996), and it is one of the most abundant Brachyura in the salt marshes of the estuarine region of the Lagoa dos Patos Lagoon. Among brachyurans inhabiting the estuarine region of Lagoa dos Patos, the natural diet has been studied in detail only for Callinectes sapidus (Oliveira et al., 2006). For Neohelice granulata, qualitative information about natural diet has indicated that this is an omnivorous species, mainly detritivorous (D'Incao et al.,

*Author for correspondence: robertabarutot@ig.com.br 
1990). Cannibalism has also been often observed (Luppi et al., 2001).

Considering its importance, more detail is needed regarding the natural diet of this crab, and the present investigation addresses this issue by means of a quantitative assessment of food items consumed and the seasonal variation in diet of $N$. granulata.

\section{MATERIALS AND METHODS}

The study area comprised two salt marshes in the estuarine region of the Lagoa dos Patos. The first, "Prainha", near to the mouth of the estuary $\left(32^{\circ} 09^{\prime} 011^{\prime \prime} \mathrm{S}\right.$; 52 $\left.06^{\prime} 02^{\prime \prime} \mathrm{W}\right)$, and the second, "Ilha", in an inner region of the estuary (31 ${ }^{\circ} 58^{\prime} 99^{\prime \prime}$ S; 52 06'75" W) (Fig. 1).

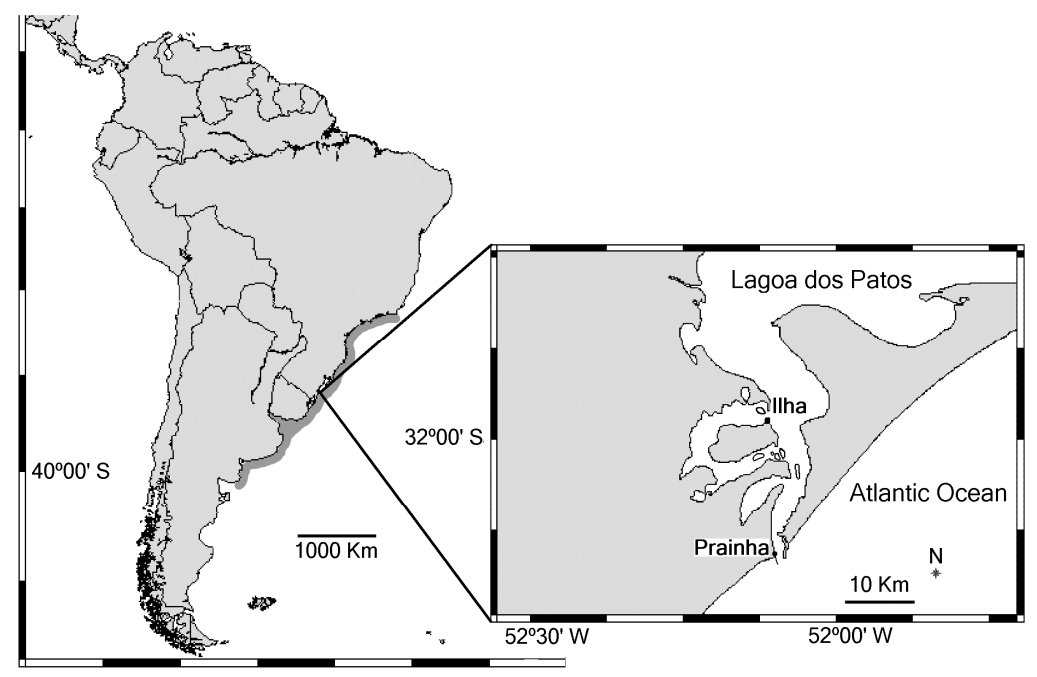

Figure 1 - Map of South America indicating the distribution range of Neohelice granulata (Dana, 1851) (grey shading). Estuarine region of the Lagoa dos Patos Lagoon is shown (inset), and sampling sites are indicated $(\bullet)$.

Sampling was seasonal (October/2003, April/2004, July and January/2005, for spring, summer, autumn and winter, respectively) at both the salt marshes. The crabs were manually caught during low water periods. Sampling was carried out always by the same experienced researchers, who sought crabs during a fixed period of one hour. In the laboratory, a random subsample of the total catch was taken for analysis. Crabs selected were immediately fixed in $4 \%$ formaldehyde, and after $24 \mathrm{~h}$, they were preserved in $70 \%$ ethanol. Each crab was measured (carapace width - CW -, nearest $0.01 \mathrm{~mm}$ ) and weighed (W, nearest $0.01 \mathrm{~g}$ ), and the foregut was dissected out and weighed (FW, nearest $0.001 \mathrm{~g})$. Mean repletion index (RI) was estimated as the average FW/W for each season.

Foreguts fullness (SF, \%) was recorded as the subjective estimate (Wear and Haddon, 1987), as follows: empty (0\%), moderately full $(0.1-30 \%)$, full $(30.1-70 \%)$, and very full $(70.1-100 \%)$. Further, foreguts were opened in a Petri dish and the contents were diluted in $1 \mathrm{ml}$ alcohol with Begal Rose.

To quantify the food items, diluted contents were placed in Sedgewick Rafter ${ }^{\circledR}$ slide, and the number of occurrences of each item was recorded. Two approaches were utilised: frequency of occurrence and points method (Williams, 1981; Wear and Haddon, 1987). These two approaches are widely applied in studies regarding the natural diet of crustaceans. Moreover, they provide different pieces of information, as the former is a measure of food preference and the latter is a quantitative measure of occurrence of each food item in the diet.

Diet composition at the sampling level was summarised by the percent frequency of occurrence of a food item i (FO) as the ratio between the number of foreguts which contained an item i (FO), and the total number of analysed foreguts (n), excluding the empty foreguts $-\% \mathrm{FO}=$ FO/n (Williams, 1981). 
Individual patterns of diet were evaluated by the points methods. The relative contribution of each food item i (RCi) in a foregut was subjectively classified in five categories (Wear and Haddon, 1987): $0-5 \%=2.5$ point, $5.1-35 \%=25$ points, $35.1-65 \%=50$ points, $65.1-95 \%=75$ points, and $95.1-100 \%=100$ points. Further, RCi was weigted according to the foregut fullness in which food item $\mathrm{i}$ was found, as follows: empty, 0.25; moderately full, 0.5; full, 0.75; and very full, 1.00 (Wear and Haddon, 1987), which resulted in the absolute frequency of points for a food item i found in the foregut $\mathrm{j}$ (PFaij). The relative frequency of points (FP) of a food item was estimated as $\mathrm{FP}=\Sigma \mathrm{jn}=\mathrm{i}(\mathrm{PFaij} / \mathrm{A}) \times 100$, where $\mathrm{A}$ is the total number of points of all food items in the foregut $\mathrm{j}$ (Williams, 1981).

To test the possible significant differences between the frequencies of occurrence of the items consumed by the males and females, the $\chi^{2}$ test was used to the level of 5\% of significance and n-1 degrees of freedom $(n=2)$. Seasonal comparisons were performed using ANOVA. Normality was assessed using Kolmogorov-Smirnov test (Zar,
1996). Cluster analysis was performed to explore alimentary similarities amongst sexes and seasons. The relative frequency of point was utilized a data source for cluster analysis. For this analysis, the distance measurement which resulted in the highest cophenetic correlation coefficient was chosen. Cluster analysis was carried out using the PAST software (Hummer et al., 2001).

\section{RESULTS}

A total of 449 foreguts was analysed, 236 from crabs caught at Prainha (120 males and 116 females) and 213 from crabs caught at Ilha (104 males and 109 females). From the analysed foreguts, $10.1 \%$ and $3.3 \%$ were empty at Prainha and Ilha, respectively. Mean repletion index varied seasonally, with significant higher values found in spring-summer than in autumn-winter (ANOVA; $\mathrm{P}$ $<0.05$ for both sites; Prainha: Fcalculated $=15,04$ and Fcritical $=2,65$; Ilha: Fcalculated $=3,79$ and Fcritical=2,69) (Fig. 2).

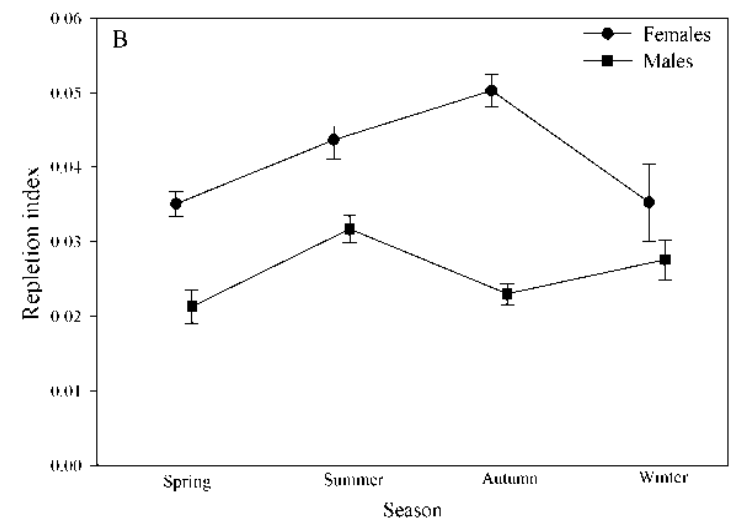

Figure 2 - Seasonal repletion index of foreguts of males and females caught at (A) Prainha and (B) Ilha. Mean \pm standard error.

Food items were grouped into seven categories: sediment, Spartina spp., crustaceans, molluscs, plant detritus, animal detritus, and indeterminate. Items with the highest frequency of occurrence, at both sites, were sediment, Spartina sp. and plant detritus. Animal detritus was the fourth most frequent item (Tables 1 and 2). The least frequent items were molluscs, which was found only in spring, and indeterminate. Seasonally, significant differences were found $\left(\chi^{2}\right.$ test) between the males and females in the frequency of occurrence of food items at both sites (Tables 1 and 2). At Ilha, the main differences found between sexes were observed in the spring, autumn and winter, while at Prainha the differences were found in summer and winter. The highest percentage of points were found year round for plant detritus, sediment and Spartina sp. at both sites (Fig. 3). Animal detritus had an intermediate percentage. For all the repletion indexes, significant correlations were found between the crab weight and foregut weight (moderately full $\mathrm{n}=38, \mathrm{r}=0.63, \mathrm{p}<0.001$; full $\mathrm{n}=31$, 
$\mathrm{r}=0.88, \mathrm{p}<0.001$; and very full $\mathrm{n}=26, \mathrm{r}=0.80$, $\mathrm{p}<0.001)$.

The cluster analysis detected five groups as follows: (1) spring males from both the locations; (2) winter females from both the locations; (3) summer males and females from both locations; (4) winter males and spring females from both the locations and; (5) autumn males from both the locations plus autumn females from Prainha. Only autumn females from Ilha was found isolated from the others (Fig. 4).

\section{DISCUSSION}

At both the sites year round no shifts were observed in the diet of $N$. granulata. Sediment, Spartina sp. and plant detritus were the items with the highest FO and \%FP. These results agree with an earlier investigation (D'Incao et al., 1990) in which "sediment" and "plants" were the most observed items in the diet year round. Animal detritus had also an important contribution in the natural diet of this crab.

Regarding the item sediment, high FO and \%FP were consistently found. A question is about the relative importance of the deliberate ingestion of sediment or if it is ingested along other food items, particularly plant material such as Spartina sp. Neohelice granulata is understood as a deposit feeder, and the isotopic $\mathrm{C}$ signature has demonstrated the importance of Spartina detritus in the diet (Botto et al., 2005). However, it has been shown elsewhere that $N$. granulata do affect the production of Spartina densiflora by herbivory on new shoots (Bortolus and Iribarne, 1999). While enzymatic activities in the gut of $N$. granulata remain not understood, caution should be taken regarding a categorical statement on the relative importance of organic matter and plant material in the diet of this species. For instance, a high activity of cellulase would support the importance of plant material in the diet of this crab.

Alternatively, the consumption of plant material, even in the absence of gut cellulase, could operate by enrichment of the substrate for further production of organic matter. Salt marshes are environments in which energy flux in the ecosystem is mainly based on the detritivorous chain (Zimmer et al, 2004). Crabs in high densities, such as those observed for $N$. granulata, grazing on plant material, play an important role in ecosystem as they transfer an high amount of the producers biomass to organic matter pool. Actually, even passively $N$. granulata increases the organic matter content of the substrate as theirs burrows trap detritus (Botto and Iribarne, 2000).

In a study carried out in mangroves, $N$. granulata was classified as a functional herbivore given the prevalence of plant material in the foreguts analysed (Brogim and Lana, 1997). However, it has been suggested that this classification may vary according to the environment considered (Brogim and Lana, 1997). According to this rationale, the same species could occupy different trophic levels in different environments, as a spatio-temporal variability in the availability of food items could lead to changes in feeding behaviour.

Particularly for the estuarine region of the Lagoa dos Patos, salt marshes are subject to sudden temporal environmental changes. Precipitation and wind regime determine the estuary hydrodynamics (Garcia, 1997), resulting in changes in the macrofauna composition according to the season (D'Incao, 1991). However, floristic and sediment composition do not vary seasonally (Costa, 1997), and therefore, are items which are easily available year round for $N$. granulata.

Crustacean detritus were found in small quantities. It is well known that the ingestion of exuviae is important for cuticle hardening after moulting (Hartnoll, 1982). Moreover, cannibalism is reported for N. granulata (Luppi et al., 2001) as adults heavily prey on settlers. Therefore it is likely that crustacean detritus found were from $N$. granulata. Supporting evidence was found in a previous study (D'Incao et al., 1990) in which it was reported carapace parts of $N$. granulata as a food item. It is important to note that the tanaid Kalliapseudes schubartii is heavily preyed on by decapods in estuarine region of the Lagoa dos Patos (Fonseca and D'Incao, 2006). Therefore, it is possible that $\mathrm{K}$. schubartii may be included in the crustacean detritus category.

Considering both the sites studied, no clear differences were found in the diet of the crabs. The same food items were found and very similar FO and $\% \mathrm{FP}$ were observed. 
Table 1 - Seasonal percent frequency of occurrence (FO) of food items found in the foreguts of males and females from Ilha. $\chi^{2}$ values are in the brackets. Stars represent a significant difference $\left(\chi^{2}\right.$ test, $\left.\mathrm{DF}=1\right)$.

\begin{tabular}{|c|c|c|c|c|c|c|c|c|}
\hline \multirow[b]{2}{*}{ Item } & \multicolumn{2}{|c|}{ Spring } & \multicolumn{2}{|c|}{ Summer } & \multicolumn{2}{|c|}{ Autumn } & \multicolumn{2}{|c|}{ Winter } \\
\hline & Males & Females & Males & Females & Males & Females & Males & Females \\
\hline Sediment & $\begin{array}{c}42.1 \\
(0.11)\end{array}$ & 57.9 & $\begin{array}{c}49.0 \\
(0.83)\end{array}$ & 51.0 & $\begin{array}{c}61.1 \\
(0.02)\end{array}$ & $38.9 *$ & $\begin{array}{c}68.4 \\
(0.0002)\end{array}$ & $31.6^{*}$ \\
\hline Spartina sp. & $\begin{array}{c}40.0 \\
(0.04)\end{array}$ & $60.0^{*}$ & $\begin{array}{c}49.0 \\
(0.83)\end{array}$ & 51.0 & $\begin{array}{c}61.1 \\
(0.02)\end{array}$ & $38.9^{*}$ & $\begin{array}{c}61.1 \\
(0.02)\end{array}$ & $38.9 *$ \\
\hline Crustaceans & $\begin{array}{c}80.0 \\
\left(1.97 . \mathrm{E}^{-09}\right)\end{array}$ & $20.0^{*}$ & $\begin{array}{c}7.7 \\
\left(2.63 . \mathrm{E}^{-17}\right)\end{array}$ & $92.3^{*}$ & $\begin{array}{c}0 \\
\left(1.52 . \mathrm{E}^{-23}\right)\end{array}$ & $100 *$ & $\begin{array}{c}0 \\
\left(1.52 . \mathrm{E}^{-23}\right)\end{array}$ & 0 \\
\hline Molluscs & $\begin{array}{c}0 \\
\left(1.52 . \mathrm{E}^{-23}\right)\end{array}$ & $100^{*}$ & $\begin{array}{c}0 \\
\left(1.52 . \mathrm{E}^{-23}\right)\end{array}$ & 0 & $\begin{array}{c}0 \\
\left(1.52 . \mathrm{E}^{-23}\right.\end{array}$ & $100 *$ & $\begin{array}{c}0 \\
\left(1.52 . \mathrm{E}^{-23}\right)\end{array}$ & 0 \\
\hline Plant detritus & $38.1(0.01)$ & $61.9 *$ & $\begin{array}{c}50.0 \\
(1)\end{array}$ & 50.0 & $\begin{array}{c}61.1 \\
(0.02)\end{array}$ & $38.9^{*}$ & $\begin{array}{c}65.0 \\
(0.002)\end{array}$ & $35.0 *$ \\
\hline Animal detritus & $\begin{array}{c}29.4 \\
\left(3.82 . \mathrm{E}^{-05}\right)\end{array}$ & $70.6^{*}$ & $\begin{array}{c}11.1 \\
\left(7.38 . \mathrm{E}^{-15}\right)\end{array}$ & $88.9 *$ & $\begin{array}{c}54.8 \\
(0.33)\end{array}$ & 45.2 & $\begin{array}{c}87.5 \\
\left(6.38 . \mathrm{E}^{-14}\right)\end{array}$ & $12.5^{*}$ \\
\hline Indeterminate & $\begin{array}{c}0 \\
\left(1.52 . \mathrm{E}^{-23}\right)\end{array}$ & $100 *$ & $\begin{array}{c}0 \\
\left(1.52 . \mathrm{E}^{-23}\right)\end{array}$ & 0 & $\begin{array}{c}0 \\
\left(1.52 . \mathrm{E}^{-23}\right)\end{array}$ & 0 & $\begin{array}{c}0 \\
\left(1.52 . \mathrm{E}^{-23}\right)\end{array}$ & 0 \\
\hline
\end{tabular}

Table 2 - Seasonal percent frequency of occurrence (FO) of food items found in the foreguts of males and females from Prainha. $\chi^{2}$ values are in the brackets. Stars represent a significant difference $\left(\chi^{2}\right.$ test, $\left.\mathrm{DF}=1\right)$.

\begin{tabular}{|c|c|c|c|c|c|c|c|c|}
\hline \multirow[b]{2}{*}{ Item } & \multicolumn{2}{|c|}{ Spring } & \multicolumn{2}{|c|}{ Summer } & \multicolumn{2}{|c|}{ Autumn } & \multicolumn{2}{|c|}{ Winter } \\
\hline & Males & Females & Males & Females & Males & Females & Males & Females \\
\hline Sediment & $\begin{array}{c}40.7 \\
(0.06)\end{array}$ & 59.3 & $\begin{array}{c}30.2 \\
\left(7.24 . \mathrm{E}^{-5}\right)\end{array}$ & $69.8^{*}$ & $\begin{array}{c}57.9 \\
(0.11)\end{array}$ & 42.1 & $\begin{array}{c}60.9 \\
(0.02)\end{array}$ & $39.1^{*}$ \\
\hline Spartina sp. & $\begin{array}{c}42.9 \\
(0.15)\end{array}$ & 57.1 & $\begin{array}{c}29.0 \\
\left(2.74 . E^{-5}\right)\end{array}$ & $71.0^{*}$ & $\begin{array}{c}57.9 \\
(0.11)\end{array}$ & 42.1 & $\begin{array}{c}60.0 \\
(0.04)\end{array}$ & $40.0^{*}$ \\
\hline Crustaceans & $\begin{array}{c}57.1 \\
(0.15)\end{array}$ & 42.9 & $\begin{array}{c}10.5 \\
\left(2.90 . \mathrm{E}^{15}\right)\end{array}$ & $89.5^{*}$ & $\begin{array}{c}28.6 \\
\left(1.82 . E^{-5}\right)\end{array}$ & $71.4^{*}$ & $\begin{array}{c}0 \\
\left(1.52 \cdot \mathrm{E}^{-23}\right)\end{array}$ & $100 *$ \\
\hline Molluscs & $\begin{array}{c}50.0 \\
(1)\end{array}$ & 50 & $\begin{array}{c}0 \\
\left(1.52 . \mathrm{E}^{-23}\right)\end{array}$ & 0 & $\begin{array}{c}0 \\
\left(1.52 . \mathrm{E}^{-23}\right)\end{array}$ & 0 & $\begin{array}{c}0 \\
\left(1.52 . \mathrm{E}^{-23}\right)\end{array}$ & 0 \\
\hline Plant detritus & $\begin{array}{c}42.9 \\
(0.15)\end{array}$ & 57.1 & $\begin{array}{c}29.7 \\
\left(4.85 . E^{-5}\right)\end{array}$ & $70.3^{*}$ & $\begin{array}{c}57.9 \\
(0.11)\end{array}$ & 42.1 & $\begin{array}{c}62.5 \\
(0.01)\end{array}$ & $37.5^{*}$ \\
\hline Animal detritus & $\begin{array}{c}42.1 \\
(0.11)\end{array}$ & 57.9 & $\begin{array}{c}6.5 \\
\left(3.04 \cdot \mathrm{E}^{-18}\right)\end{array}$ & $93.5^{*}$ & $\begin{array}{c}73.7 \\
\left(2.17 . \mathrm{E}^{-6}\right)\end{array}$ & $26.3^{*}$ & $\begin{array}{c}100^{*} \\
\left(1.52 . \mathrm{E}^{-23}\right)\end{array}$ & $0^{*}$ \\
\hline Indeterminate & $\begin{array}{c}0 \\
\left(1.52 . \mathrm{E}^{-23}\right)\end{array}$ & $100 *$ & $\begin{array}{c}0 \\
\left(1.52 \cdot \mathrm{E}^{-23}\right)\end{array}$ & $100 *$ & $\begin{array}{c}0 \\
\left(1.52 \cdot \mathrm{E}^{-23}\right)\end{array}$ & 0 & $\begin{array}{c}0 \\
\left(1.52 . \mathrm{E}^{-23}\right)\end{array}$ & $100 *$ \\
\hline
\end{tabular}




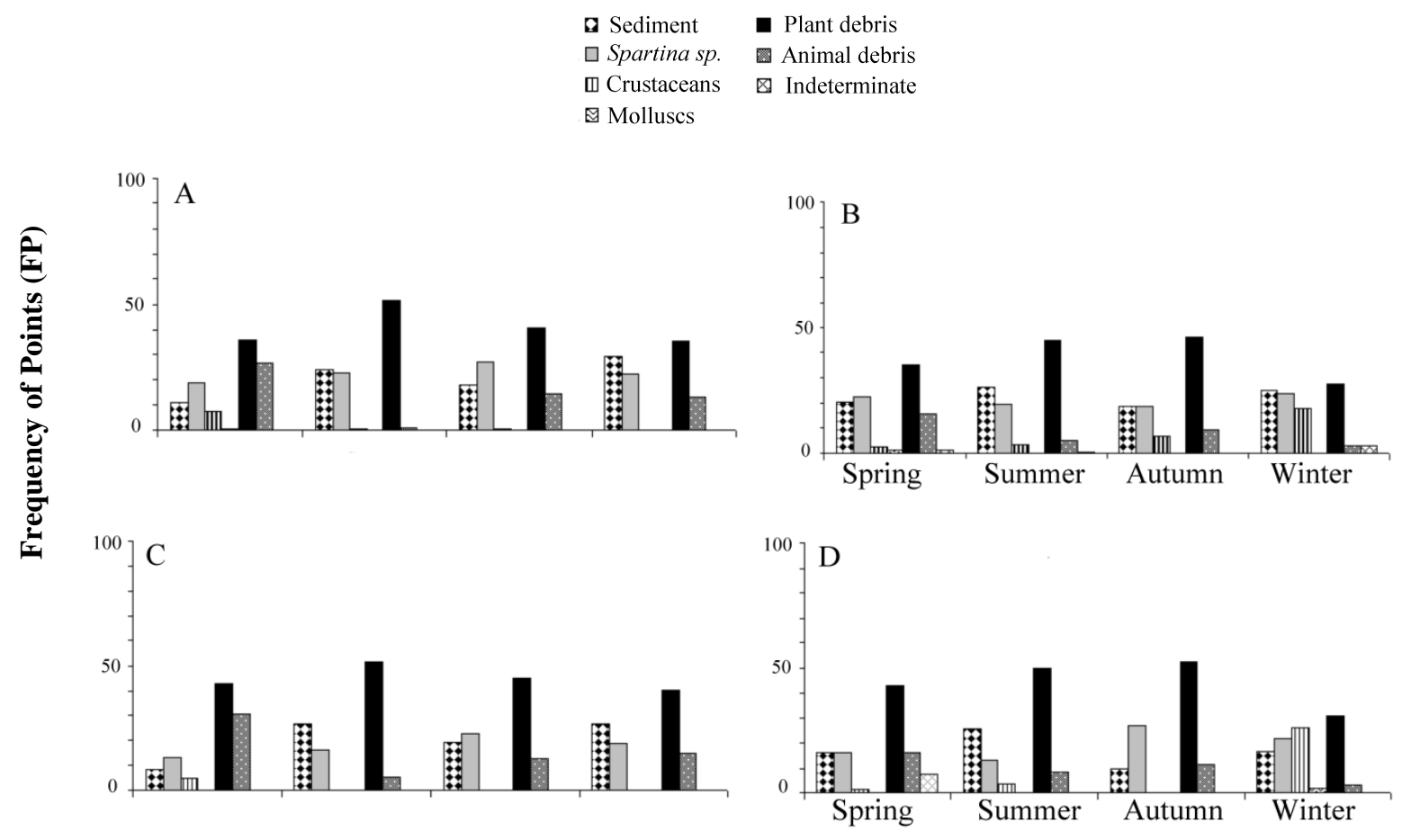

Figure 3 - Relative frequency of points of the food items found in the foreguts of (A) males and (B) females from Prainha, and (C) males and (D) females from Ilha.

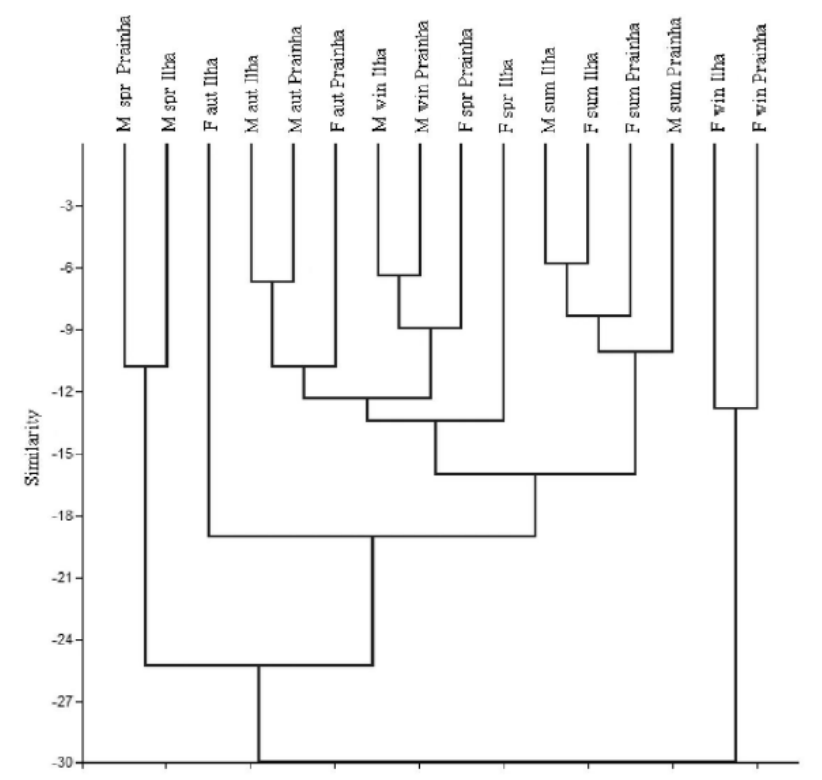

Figure 4 - Cluster analysis between seasons (cophenetic correlation coefficient=0.8781). M= males, $\mathrm{F}=$ females, spr= spring, sum= summer, aut=autumn and win= winter.

The Cluster analysis clearly showed the males and females of both sites in summer, which was probably due food abundance that reduced the competition. For the other seasons, there was a greater differentiation for both the sexes and for the sites. The males behaved similarly in the spring while the females in the winter. Only the females of autunm from Ilha were found 
separately in the analysis.

Actually, both the salt marshes have similar floristic composition, and the only noticeable difference is the anthropogenic impact observed in the salt marsh Prainha (Costa et al., 1997). Another difference found was the higher repletion index found for the females caught in autumn at the salt marsh Ilha. This higher repletion index was at odds with the pattern found for both the sexes at Prainha and for the males from Ilha. This particular high repletion index was the result of an unexpected high proportion of the females with full foreguts. Despite this difference in fullness, no marked shifts were found in the FO and \% FP of all the food items analysed for the females from Ilha and Prainha.

\section{ACKNOWLEDGEMENTS}

This study was supported by a Ph.D. studentship to R.A.B., a researcher scholarship to F.D., and a Post-Doc scholarship to D.B.F. from the Brazilian Government through The National Council for Scientific and Technological Development (CNPq). R.A.B. would like to thank Ms Andrea Gerusa Ribeiro Barros and Ms Derien Lucie Vernetti Duarte for the help in processing samples.

\section{REFERENCES}

Bortolus, A and Iribarne, O. (1999), Effects of the SW Atlantic burrowing crab Chasmagnathus granulata on a Spartina salt marsh. Mar. Ecol. Prog. Ser., 178, 79-88.

Botto, F. and Iribarne, O. (2000), Contrasting effects of two burrowing crabs (Chasmagnathus granulata and Uca uruguayensis) on sediment composition and transport in estuarine environments. Est. Coast. and Shelf Sci., 51, 141-151

Botto, F.; Valiela, I.; Iribarne, O.; Martinetto, P. and Alberti, P. (2005), Impact of burrowing crabs on C and $\mathrm{N}$ sources, control, and transformations in sediments and food webs of SW Atlantic estuaries. Mar. Ecol. Prog. Ser., 293, 155-164.

Brogim, R. A. and Lana P. C. (1997), Espectro alimentar de Aratus pisonii, Chasmagnathus granulata e Sesarma rectum (Decapoda, Grapsidae) em um manguezal na Baía de Paranaguá, Paraná. Iheringia, 83, 35-43.
Costa, C. S. B. (1997), Tidal Marsh and Wetland Plants. In: Seeliger, U.; Odebrecht, C. and Castelo, J. P. (Eds). Subtropical convergence environments: the coast and the sea in the Southwestern Atlantic. Springer, Berlin, 308p.

Costa, C. S. B.; Seeliger, U.; Oliveira, C. P. L. and Mazo, A. M. M. (1997), Distribuição, funções e valores das marismas e pradarias submersas no estuário da Lagoa dos Patos (RS, Brasil). Atlântica, 19, 67-85.

Costa, C. S. B.; Marangoni, J. C; Azevedo, A. M. G. (2003), Plant zonation in irregularly flooded salt marshes: relative importance of stress tolerance and biological interactions. J. Ecol., 91, 951-965.

D'Incao, F. (1991), Pesca e biologia de Penaeus paulensis na Lagoa dos Patos, RS. Atlântica, 13, 159169.

D'Incao, F.; Silva, K. G.; Ruffino, M. L. and Braga, A. C. (1990), Hábito alimentar do caranguejo Chasmagnathus granulata Dana, 1851 na barra do Rio Grande, RS (Decapoda, Grapsidae). Atlântica, 12, 285-293.

Fonseca, D. B. and D'Incao, F. (2006), Mortality of Kalliapseudes schubartii in unvegetated soft bottoms of the estuarine region of the Lagoa dos Patos. Braz. Arch. Biol. Technol., 49 (2), 257-261.

Garcia, C. A. E. (1997), Hydrographic characteristics. In: Seeliger, U.; Odebrecht, C. and Castelo, J. P. (Eds). Subtropical convergence environments: the coast and the sea in the Southwestern Atlantic. Springer, Berlin, 308p.

Gutiérrez, J. L; Jones, C. G; Groffman, P. M; Findlay, S. E. G.; Iribarne, O.; Ribeiro, P. D. and Bruschetti, C. M. (2006), The contribution of crab burrow excavation to carbon availability in surficial saltmarsh sediments. Ecosystems, 9, 647-658.

Hartnoll, R. G. (1982), Growth In: The biology of Crustacea. Vol. 8. Enviromental adaptations. Vernberg and Vernberg (Ed.), Academic Press. New York. 383p.

Hummer, O. Harper, D.A.T. and Ryan, P.D. (2001), PAST: Paleontological Statistics software package for education and analysis. Paleont. Elet., 4 (1), 9pp.

Lana, P. C and Guiss, C. (1992), Macrofauna-plantbiomass interactions in a euhaline salt marsh in Paranagua bay (SE Brazil). Mar. Ecol. Prog. Ser., 80, 57-64.

Luppi, T. A.; Spivak, E. D. and Anger, K. (2001), Experimental studies on predation and cannibalism of the settlers of Chasmagnathus granulata and Cyrtograpsus angulatus (Brachyura: Grapsidae). J. Exp. Mar. Biol. Ecol., 265, 29-45.

Melo, G. A. S. (1996), Manual de identificação dos Brachyura (caranguejos e siris) do litoral brasileiro. Plêiade, São Paulo. 604p. 
Oliveira, A.; Pinto, T. K.; Santos, D. P. D. and D'Incao, F. (2006), Dieta natural do siri-azul Callinectes sapidus (Decapoda, Portunidae) na região estuarina da Lagoa dos Patos, Rio Grande, Rio Grande do Sul, Brasil. Iheringia Sér. Zool., 96, 305-313.

Wear, R. G. and Haddon, M.. (1987), Natural diet of the crab Ovalipes catharus (Crustacea, Portunidae) around central and northern New Zealand. Mar. Ecol. Prog. Ser., 35, 39-49.
Williams, M. J. (1981), Methods for analysis of natural diet in portunid crab (Crustacea: Decapoda: Portunidae). J. Exp. Mar. Biol. Ecol., 52, 103-113.

Zar, J. H. (1996), Biostatistical Analyses. Third Edition. Prentice Hall, New Jersey, USA. 121p.

Zimmer, M.; Pennings, S. C.; Buck, T. L. and Carrefoot, T. (2004), Salt marsh litter and detritivores: a closer look at redundancy. Estuaries, 27 (5), 753-769. 